\title{
Az Állattani Szakosztály ülései (2018. december 5. - 2019. szeptember 20.)
}

\author{
TÓTH BALÁZs* \\ Magyar Természettudományi Múzeum Állattára, 1088 Budapest, Baross u. 13. \\ E-mail: toth.balazs@nhmus.hu
}

Az előadásokról videófelvételek készülnek, amelyek szerkesztés után felkerülnek a Szakosztály nyilvános YouTube-csatornájára. Ennek megfelelően a levezető elnök minden előadóülés elején bejelenti, hogy az előadások a továbbiakban videokamerával rögzítésre kerülnek, és a felvételeken történő megjelenést a hallgatóság tagjai az ülésen történő további részvétellel vállalják. A felvételek rögzítését, szerkesztését és feltöltését SULYÁN PÉTER végzi, akinek ezúton is köszönetemet fejezem ki, mert munkájával nagymértékben megkönnyítette jelen összefoglaló elkészítését.

\section{9. előadóülés, 2018. december 5-én}

Az ülés levezető elnöke NAGY PÉTER elnök úr volt.

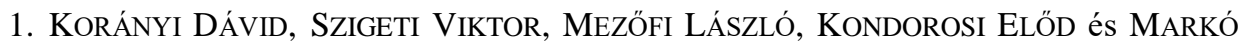
VIKTOR: Juharfák levéltetü és izeltlábú ragadozó együttesének szervezödése urbanizációs gradiens mentén.

Ha a jelenlegi trend folytatódik, akkor 2050-re a Föld népességének kétharmada városlakó lesz. E folyamat élöhelyek megszünésével, de legalább átalakulásával, valamint a környezeti feltételek megváltozásával jár. Bár szünantróp fajok az ízeltlábúak között is szép számmal előfordulnak, mégis általában mellőzik az urbanizációs vizsgálatokban ezt az állattörzset. Szerzők vizsgálatának célja a juhar-egyedek faunisztikai felmérése mellett a levéltetvek és a predátorok denzitásváltozásának feltárása volt térben és időben. Kíváncsiak voltak még arra is, hogy mely ragadozók szabályozzák legnagyobb mértékben a levéltetvek állományainak méretét. Budapesten és vonzáskörzetében összesen 22 helyszínen 3-3 juharfát vizsgáltak két éven át. Kopogtatással gyüjtöttek ízeltlábúakat. Urbanizációs gradienst állítottak fel, melynek értékeit a mesterséges felületek (aszfalt, épületek) borításának százalékos arányával fejezték ki. Összesen több mint 10000 levéltetű egyedet gyüjtöttek, melyek 9 fajhoz tartoztak. Mintegy 130 ragadozó faj közel 9000 egyedét találták (ezek majdnem egyharmada pók volt), köztük két, a hazai fanára új taxont is. Megfigyelték, hogy az urbanizációs gradiens növekedésével a levéltetvek denzitása gyorsuló ütemben nő, míg a ragadozóké és a hangyáké egyenletesen csökken. A levéltetvek tavasszal és ősszel voltak gyakoriak, a ragadozók denzitása folyamatosan nőtt és ősszel volt a legmagasabb, míg a

\footnotetext{
*Az Állattani Szakosztály jegyzője
} 
hangyáknál nem mutattak ki egyértelmű trendet. A ragadozó fajok nagy része mindenféle helyszínen előfordult, de egyaránt találtak az urbánusabb helyszínekre jellemző (pl. hársfabodobács) és a természetesebb helyekhez kötődő fajokat (pl. hálószövő pókok). A beépítettséggel nőtt a ragadozó együttesek fajgazdagsága. Elmondható tehát, hogy a ragadozóegyüttesek összetétele változik a beépítettség mértékével. A hangyák és a levéltetvek denzitása nem függött egymástól, ám egyik évben a ragadozók egyedsürüsége befolyásolta a levéltetvekét. SZÖVÉNYI GERGELY megkérdezte, hogy a levéltetvek nem váltanak-e gazdanövényt. Előadó elmondta, hogy általában nem, viszont több faj nyáron diapauzába vonul. SzÖVÉNYI GERGELY: Mire alapozzák, hogy a ragadozók alakítják a levéltetvek egyedsürüségét, és nem fordítva? KORÁNYI DÁVID: A beépítettség a fö magyarázó változó: jobban beépített területen kevesebb ragadozó volt jelen, természetesebb helyszínen több, itt nagyobb lehetett a hatásuk - ez óvatos következtetés, nem vizsgálták alaposabban a predátorok és levéltetvek közötti viszonyokat. NAGY PÉTER: Vizsgálták azt, hogy a levéltetvek kártétele mennyire volt súlyos, mennyire befolyásolták a fék egészségét? KORÁNYI DÁVID: Igen, egy másik vizsgálatuk alapján jelentősen nő a fák stressz-szintje (nő a reaktív oxidációs termékeket semlegesítő vegyületek kibocsátása).

Előadónak ez volt az első előadása a Szakosztály ülésein.

2. HAFEnscher ViKTÓRIA Priszcilla, HorvÁth Gergely, BALÁzs Gergely és HERCZEG GÁBOR: Hosszútávú izoláció hatása barlangi víziászkák (Asellus aquaticus) táplálékpreferenciájára.

Az előadás kezdete előtt NAGY PÉTER elnök úr kiemelte, hogy Előadó korábban még nem tartott előadást az Állattani Szakosztályban.

A felszíni és barlangi természeti viszonyokban nagy különbségek vannak: a felszín alatt egyszerübbek a táplálékhálózatok és kevesebb a táplálék, a természetes fény hiánya miatt; továbbá a barlangokban a környezeti tényezők (pl. hőmérséklet) jóval kevésbé változnak, mint a felszínen. E viszonyokhoz történő alkalmazkodás morfológiai változásokat is eredményez (troglomorfizmus), pl. a pigmentáció vagy a szemek visszafejlődését. Előadó és szerzőtársai a budapesti Molnár János- és a mangaliai (Románia) Movile-barlangban végezték kutatásukat; mindkét helyszín termál-kemoautotróf barlang, ahol kén-oxidáló baktériumok termelnek tápanyagot Szerzők feltételezése szerint. Arra a kérdésre keresték a választ, hogy a barlangi kolonizáció átalakította-e a táplálékpreferenciát. A Movile-barlang környezetében egyrészt felszíni vizekből gyüjtöttek mintákat - oxigéndús és intenzív kénvegyülettermelő környezetben egyaránt, másrészt a barlangban lévő víztestben is fogtak víziászkákat. Víz alatt szippantóval gyüjtöttek. E barlang terepviszonyai és élővilága is igen változatosak. A Molnár János-barlangból és környezetéből szintén több helyröl származtak a kísérleti víziászkaegyedek. Mindegyik helyszínről 25-25 hím és nőstény példányt vontak be a vizsgálatokba, melyek során először a szokásos táplálékot kapták (felszíni vizek: hullott levelek, barlangi vizek: baktériumfilm), és videóra vették tevékenységüket. Pihenő után megcserélték a táplálékot, és ismét videózták az állatokat. Minden egyedet végig az élőhelyének megfelelő fényviszonyok között tartottak. Eredményeik szerint a barlangi egyedek jóval több ideig táplálkoztak, és ezt jóval hamarabb kezdték el, mint a felszíniek. A barlangi példányok sokkal hosszabb ideig táplálkoztak felszíni táplálékon, mint a baktériumfilmen. Ez utóbbi megfigyelés magyarázatára két hipotézist állítottak fel: (1) a levél tápértéke nagyobb, mint a baktériumoké, ezért többet ettek belöle, (2) szájszervük már módosult, ezért kellett több idő a táplálék elfogyasztásához. Nem találtak különbséget a barlangi és a fel- 
színi víziászkák szájszervei között, ezért a továbbiakban egyszerre terveznek felkínálni az állatoknak baktériumfilmet, levelet és az előzőeknél magasabb tápértékü haltápot. NAGY PÉTER: A táplálékválasztást az adott táplálékon eltöltött idővel fejezték ki? Nem vizsgálták, hogy ténylegesen felveszi-e, pl. béltartalom-vizsgálattal? HAFENSCHER PRISZCILLA: Valóban az ott töltött időt tekintették meghatározónak, a béltartalom vizsgálatára nem volt lehetőségük. NAGY PÉTER: Izotópos jelölésre van-e mód? HERCZEG GÁBOR: Más kísérletek alapján nem tartották érdemesnek próbálkozni ilyen vizsgálattal. NAGY PÉTER: A szakterületen elfogadott, hogy a táplálékválasztást az adott táplálékon eltöltött idővel fejezik ki? HERCZEG GÁBOR: Jelenleg nem ismernek jobb módszert, és ezzel többféle adatot rögzíteni lehet. A viselkedés pontosabb megfigyelésével lehetne javítani az adatok minőségén. FONÓ PÁL: A felszíni víziászkák a baktériumfilmen kevesebb időt töltöttek, mint a leveleken. Ennek az a magyarázata, hogy egyszerübb rajta táplálkozni, vagy inkább az, hogy nem kedvelik? HAFENSCHER PRISZCILlA: Valószínüleg inkább nem szeretik. SzÖVÉNYI GERGELY: Vizsgálták, hogy ténylegesen mennyire táplálóak a különböző táplálékok? Anyagösszetételüket lehetne megnézni. HAFENSCHER PRISZCILLA: Nem vizsgálták, de az anyagösszetétel tanulmányozása kivitelezhető.

3. SzÖVÉNYI GERGELY és PUSKÁS GELLÉRT: Szöcskék sáskák és tájak orthopterológiai kirándulásokon a Dinaridákban.

A Dinaridák a szlovéniai Karszt-hegységtől kb. 600 km hosszan Albániáig nyúlik. Nagyon tagolt, három fö övre osztható. (A Dinári-hegység elnevezés igazából csak a központi övre vonatkozik.) A belső övben nagy erdőborítást láthatunk, a középső és külső övben kopár mészkőszikla-felszínek is előfordulnak.

Az Učka-hegység Rijeka közelében található, szép szubmediterrán élőhelyek találhatók rajta. A Poecilimon elegans pókszöcskét innen írták le. Cres szigetén már a sík vidékeken lehet különleges fajokat találni, pl. egy, Trieszt mellöl leírt sáskafajt, mely Horvátországból csak innen ismert (Szerzők találták meg). A Velebit-hegységben a jellegtelennek tűnő bozótosok rejtik az egyik szűk elterjedésü (máshol nem ismert) sáskafajt. A hegységben 1800 m körül párnanövényzet él. A Poštak-hegyvonulat a bosnyák-horvát határon húzódik, déli oldalán nagy kiterjedésű szubmediterrán gyepek vannak, melyek közé kisebb erdőfoltok, bozótosok ékelődnek. Itt él a Pholidoptera frivaldszkyi avarszöcske legnyugatabbi állománya, e fajt HERMAN OTTÓ írta le. Nyugat-Boszniában helyezkedik el a Livanjsko Polje, egy nagy kiterjedésü fennsík a hegyláncok között. Nedvesebb és szárazabb kaszálórétek, kiszáradó tavak tarkítják. Kissé keletebbre találjuk a Cincar-hegységet, nagy kiterjedésü gyepeivel. A Pachytrachys bosniacus fajt Szerzők fedezték fel újra, előttük csak a két típuspéldány volt ismert. A területen még ma is sok aknamező van! A Čvrsnica-hegység majdnem 2300 m magas, igen tagolt. Mostarhoz közel található a Prenj-hegység, amely nehéz terepviszonyokkal bír: meredek sziklafalak és kiterjedt karrmezők tarkítják. A Bjelašnica-hegység volt a szarajevói téli olimpia egyik helyszíne, $2000 \mathrm{~m}$ fölé magasodik. Talán ez a tengertől legtávolabb eső olyan hegység, ahol elsődleges gyepek borította fennsíkok vannak. Az Apolló-lepke (Parnassius apollo) gyakori itt. A Varda-hegység már a szerb határhoz közel helyezkedik el. Szerpentinit az alapkőzete, amely különleges mikroklímát biztosít: morzsolódik, de a vizet nem nyeli el, ezért a hegység felszíni vizekben gazdag. Itt egy, még leíratlan sáskafajt is találtak a Szerzők. A Pyrgomorphula serbica sáska különleges alakú, nagyon szük elterjedésü, veszélyeztetett faj. A montenegrói határnál fekszik a Sutjeska Nemzeti Park, Bosznia legmagasabb csúcsával és nagy kiterjedésü, montán 
bükkös erdörezervátumokkal. Montenegróba átlépve a Durmitor-hegységet mutatták be a Szerzők. Több szöcskefajnak ez a típuslelöhelye. A Pelješac-félsziget helyenként igen keskeny, szigetként hat, ám 1000 m fölé nyúló hegylánc magasodik rajta. A Dinári-hegység legdélebbi magashegysége a Rumija, a montenegrói-albán határhoz közel, a tengerparton fekszik. Még a legmagasabb csúcsa is szubmediterrán-mediterrán klímájú. Alsó régiójában szelídgesztenyések vannak, itt több Saga-faj (fürészlábú szöcskék) is él. Ezek mellett Szerzők éjszaka megtaláltak egy, addig inkább csak barlangokból ismert szöcskefajt. A Prokletije-hegység nagyon tagolt, a Dinári-hegység legmagasabb csúcsa itt található. A homoki vipera különösen gyakori itt. Koszovó és Albánia határán található a Pashtrikhegység, amely számos botanikai különlegességet rejt. Északi lejtőin sztyepi fajok honosak, elterjedési területük szélén. NOVÁK JÁNOS kérdése: Tervezik-e az újra megtalált Pachytrachys bosniacus újra-leírását, esetleg újonnan felfedezett morfológiai bélyegek alapján? SzÖVÉNYI GERGELY: Az eredeti leírás elég részletes, ezért nem szeretnék újraleírni a fajt, ugyanakkor dolgoznak a genusz revízióján, molekuláris bélyegek bevonásával. Akusztikus bélyegek is igen hasznosak, gyakran a morfológiai jelegeknél is hasznosabbak. NOVÁK JÁNOS: Lehet tudni valamit a szóban forgó típuspéldányokról? SzÖVÉNYI GERGELY: Magángyüjteményben helyezték el őket, melynek tulajdonosa meghalt; a példányok hollétét nem tudták kideríteni. Azonban nem szükséges ezeket vizsgálni, topotipikus példányok egyértelmüen ugyanahhoz a fajhoz tartoznak. FONÓ PÁL: Milyen bélyegek alapján történik fajok szinonimizálása? SZÖVÉNYI GERGELY: A szóban forgó esetben alfajokat (és nem fajokat) fognak összevonni. Kevés egyed alapján, viszonylagos bélyegek alapján állították fel az alfajt, ráadásul elterjedési területe folytonos a törzsalakkal. Más esetekben jelenleg zajlik a speciáció, ennek különböző fokozatait lehet megfigyelni az egyes taxonoknál. HERCZEG GÁBOR: A ciripelést már a terepen rögzítik, vagy hazahozzák a példányokat és itthon veszik fel? SZÖVÉNYI GERGELY: Legjobb, ha már a terepen sikerül, de hazahozzák, ha ez nem sikerül. Ideális esetben süketszobában zajlana a felvétel. Sok szöcske éjszaka ciripel. HERCZEG GÁBOR: A hegycsúcsonként eltérő taxonok esetében a genetikai vizsgálatokhoz terveznek neutrális markereket bevonni? Ezeket a morfológiai bélyegekkel összevetve megállapítható ugyanis, hogy az eltérések adaptáció eredményei-e. SzÖVÉNYI GERGELY: Pályázatot terveznek benyújtani molekuláris vizsgálatokra, módszertani segítséget és tanácsokat örömmel fogadnak. NAGY PÉTER: A helyi természetvédelmi hatóságok mennyire hatékonyak a természeti állapotok megőrzésében, a területhasználat változása mennyire veszélyezteti az élőhelyeket? SzÖVÉNYI GERGELY: A hegység északi részén a fásszárúak magasabbra hatolnak és visszaszorítják az ősi gyepeket. A déli részek országaiban bár vannak nemzeti parkok (néha elég régiek), de olyan típusú természetvédelemről nem tudnak, mint amilyen hazánkban van. A gyepek dél felé haladva egyre stabilabbnak tünnek. A montán bükkösöket sok helyen kitermelik. A délszláv háború után sok helyszínen felhagytak a gazdálkodással (jelentős részben az aknamezők miatt).

NAGY PÉTER elnök úr kellemes ünnepeket kívánva lezárta az év utolsó előadóülését. 


\section{0. előadóülés, 2019. március 6-án}

Az ülést NAGY PÉTER elnök úr vezette le.

1. Szabó Gyula, Boross Nóra, Hegyi Gergely, LaCzi Miklós és TÖRÖK JÁNOS: Egészségi állapot és rátermettség kapcsolata örvös légykapónál.

A madarak egészségi állapotát a következő változókkal lehet jellemezni: immunválasz mértékével (csökken a szaporodási siker növekedésével), a parazitáltság mértékével, a stressz-szinttel, a hematokrit értékkel (vörösvérsejtek és a vér teljes térfogatának aránya; optimális értéke van), valamint a heterofil granulociták és limfociták arányával (H/L; minél nagyobb az értéke, annál rosszabb az egyed egészségi állapota). Szerzők feltételezték, hogy a magasabb hematokrit érték és az alacsonyabb H/L arány magasabb túlélési valószínüséget, korábbi költést, nagyobb fészekaljat és nagyobb kirepülési sikert jelez, több éven keresztül. Az örvös légykapón végezték vizsgálataikat. A H/L-arányt vérkeneteken számolták, a szaporodási siker méröszámait négy éven át, a túlélési arányt három éven át figyelték. A hematokrit esetében évhatást tapasztaltak, csak egyik évben állt szignifikáns (negatív) öszszefüggésben a fiókaszámmal és a költéskezdés idejével. A H/L-arány a költéskezdés idejével és a következő évi tojások számával pozitív, míg az előző évi fiókák számával, valamint a tojásszámmal negatív összefüggésben állt. Az egészségi állapot és a túlélés között nem találtak összefüggést. Elmondható, hogy a korábbi költés jobb egészségi állapottal járt együtt; a jobb kondíciójú madarak hamarabb érkeztek meg. A tavaly több fiókát felnevelö madarak idén jobb egészségnek örvendhetnek, viszont az idén egészségesebb madarak jövőre kevesebb tojást raknak - utóbbi eredmény az évhatás, a környezeti feltételek változásának következménye lehet. A hematokrit érték több éven át mutatott összefüggéseket (a szakirodalmi eredmények szerint inkább a H/L-arány viselkedik így). A túlélés nem mutatott kapcsolatot egyik vizsgált változóval sem. Az előadás után NAGY PÉTER érdeklődött afelöl, hogyan zajlik a gyakorlatban a fészekaljméret növelése; a kutatók raknak-e a fészekbe idegen tojásokat. SZABÓ GYULA: Egyforma méretü fészekaljak között fiókákat helyeznek át, de a nem bolygatott fészekaljat is háborgatják, hogy minden madárszülö ugyannyi zavarást észleljen. NAGY PÉTER: Nem túlságosan mesterséges ez az eljárás? SZABÓ GYULA: Nem tudják megkülönböztetni a szülők a saját és idegen fiókákat. Ez egy elfogadott módszer. NAGY PÉTER: Kerestek-e összefüggést időjárási tényezőkkel, főleg hőmérséklettel? SZABÓ GYULA: Nem kerestek, ám az esetleges befolyásoló hatásokat pl. a költéskezdésnél medián kezdési idő felvételével igyekeztek kiküszöbölni. Az évhatás ettől függetlenül sokat számított. NAGY PÉTER: A meteorológiai adatokat vissza lehet nézni. TÖRÖK JÚLIA: A vizsgált madárfaj levegőből szerzi táplálékát, ami fokozott megterhelést jelent számára, és befolyásolja hematokrit értékét. Érdemes lenne a mért változókat egy talajról táplálékot szerző madárfajéval összehasonlítani. SZABÓ GYULA: Valóban befolyásolja a táplálkozási mód a hematokrit értéket, és tényleg érdekes volna eltérö táplálkozású fajokéval összehasonlítani, ám a földön táplálkozók ritkán fészkelnek odúban, így vizsgálatuk nehezebb. JÁNOSSY LÁSZLÓ: A korábban költő párok általában sikeresebbek, ám nem fenyegetheti őket az a veszély, hogy túl korán kezdik? SzABÓ GYULA: Előfordulhat ilyen, ezért a táplálékforrás (hernyók) mennyiségét is figyelik, és ha nem tiszták az összefüggések, akkor ezt a változót 
is beveszik a vizsgálatba. Jelen esetben erre nem volt szükség. A későn érkező hó is kockázatot jelent.

2. Tóth Balázs, Katona Gergely, Sulyán Péter GÁBor és BÁlint Zsolt: $A z$ Eupitheciini tribusz a Kárpát-medencében a Magyar Természettudományi Múzeum lepkegyüjteménye alapján (Lepidoptera: Geometridae, Larentiinae).

Az elöadás anyaga az Állattani Közlemények jelen kötetében olvasható.

3. BALOG LUCA ESZTER és DR. TÖRÖK JÚLIA KATALIN: Mitöl pusztul a pajor? Parazita fonálféreg kapcsolatok egy gazdán belül.

Mezőgazdasági kártevők parazitáinak vizsgálata nagy jelentőséggel bír, különösen az emberiség élelmezése szempontjából. A cserebogarak lárvái és imágói egyaránt kártevők. A fonálférgek felbecsülhetetlen mértékü és igen sokrétü hatást gyakorolnak az emberiségre, biológiai védekezéshez is használják egyes fajaikat. A pajorokban fakultatív patogén és obligát bélparazita fonálférgek két-két családjának fajai lehetnek jelen. Utóbbi csoportról igen kevés adat áll rendelkezésre, bogarakból eddig nem mutatták ki. Szerzők cserebogár- és rózsabogár-pajorok bélparazitáinak mikroszkópos és molekuláris vizsgálatát tüzték ki célul. Munkahipotézisük szerint előfordulnak olyan bélparaziták, melyek csak legyengítik gazdájukat, utat nyitva más parazita és patogén fonálférgeknek. Száz pajort vizsgáltak: testhosszt, testtömeget mértek (ezen adatokból kondíciót számítottak), majd felboncolták. Feljegyezték a fonálférgek egyedszámát és előfordulási helyét gazdaegyedenként. A féreg-egyedekről fénymikroszkópos felvételeket készítettek, lerajzolták és morfotípusokba osztották őket. Pásztázó elektronmikroszkóppal is tanulmányozták a férgeket. A vizsgált pajorok háromnegyede fertőzött, egy részük mindkét féregcsoporttal fertőzött volt. A kondíció és a patogén fertőzés mértéke negatív kapcsolatban álltak. Az elpusztult pajorok jóval fertőzöttebbek voltak, mint az életben maradtak. Az eredményekből kiderült, hogy az obligát bélparaziták nem pusztítják el a gazdaegyedet. Minél több obligát bélparazita volt jelen, annál több volt entomopatogén fonálféregből is. Nem találtak hasonló kutatást, így eredményeiket nem tudták más vizsgálattal összevetni. Az eredeti hipotézisük igaznak bizonyult. A továbbiakban szeretnék a molekuláris vizsgálatokat kiterjeszteni, még több pajort tanulmányozni, imágókat is kutatni. NAGY PÉTER kiemelte a kutatás során végzett munka nagy mennyiségét és Előadó rajzainak minőségét. DÓZSA-FARKAS KLÁRA felvetette, hogy érdemes lenne megnézni, hogy a bábok fertőzöttsége hogyan alakul. BALOG LUCA ESZTER elmondta, hogy egyetlen bábot tudtak vizsgálni, abban nem találtak férget. A pajorok nem mutatnak hajlandóságot a bábozódásra. Terepen és komposztban sem találtak bábot. SZÖVÉNYI GERGELY: A csere- és rózsabogarak pajorjai egyaránt komposztból származtak? BALOG LUCA ESZTER: A cserebogaraké szabad földből, a rózsabogaraké komposztból. SzÖVÉNYI GERGELY: Az eredmények mindkét csoportra egyformán vonatkoznak? BALOG LUCA EsZTER: Igen, nem volt különbség köztük. SzÖVÉNYI GERGELY: Ez érdekes, mert a rózsabogár-pajorok aggregáltabban helyezkedhetnek el, köztük könnyebben terjedhet a fertőzés, mint a cserebogár-lárvák esetében. BALOG LUCA ESZTER: Ilyen téren sem találtak különbséget. Külvilágban olyankor talált bélparazita/patogén férgeket, amikor elpusztult pajor volt a közelben. NAGY PÉTER: A vizsgált rendszer igen sztochasztikus, a fajok r-stratégisták. Mennyire egyértelmü, hogy a bélrendszerben élő férgek valóban paraziták? BALOG LUCA ESZTER: Egyetlen ilyen irányú kutatásról tudnak, amely csótányokat vizsgált, és nem mutatott ki kondíciócsökkenést. NAGY PÉTER megjegyezte még, hogy nem lehet mindig éles határt húzni parazitizmus, kommenzalizmus és mutualizmus között, majd felvetette, hogy mestersége- 
sen kellene fertőzni pajorokat obligát bélparazitákkal, és vizsgálni ezek fogékonyságát a patogén fertőzésekre. Köszöntötte Előadót első előadása alkalmából a Szakosztály körében, sok sikert kívánt kutatásai folytatásához, végül az előadóülést berekesztette.

\section{1., ünnepi előadóülés, 2019. május 8-án}

Az előadóülést ismét NAGY PÉTER elnök úr vezette le. Helyszíne ezúttal a Magyar Természettudományi Múzeum Ludovika téri kiállítási épülete volt.

\section{NAGY PÉTER: A 70 éves BAKONYI GÁBOR és VÁSÁRHELYI TAMÁS köszöntése.}

Előadó kiemelte BAKONYI GÁBOR és VÁSÁRHELYI TAMÁS életútjának közös pontjait: ugyanabban az évben szerezték meg diplomájukat, mindketten a szipókás rovarokat kutatták, és jeleskednek az ismeretterjesztésben, környezeti nevelésben, magukkal ragadják a hallgatóságot. Az Állattani Szakosztály munkájában tevékeny részt vállaltak. Személyiségükkel, munkásságukkal példaképként állhatnak kortársaik és az utánuk jövő nemzedékek elé. A méltatást követően Előadó a Társaság nevében köszöntötte és megajándékozta az ünnepelteket.

\section{BAKONYI GÁBOR: Válogatott szakmai ballépéseim}

Talán furcsa lehet a címválasztás a jelen ülés ünnepélyes alkalmához, de bőségesen nyújt lehetőséget visszatekintésre. Előadó fiatal korában meghatározó volt egy könyv, amely karikatúráját adja a tudósi pályának, ebböl hallhattunk egy gondolatot. Amikor tanársegéd volt, akkor a tudományos világ az ökoszisztémák alapvető müködési alapelveit kutatta. Előadó és kutatótársai nem-sugárzó nitrogénizotópot terveztek nagy mennyiségben a talajba juttatni, majd megvizsgálni, hogy az egyes élőlények milyen mennyiségben veszik ezt fel. Ketrecet helyeztek ki egy természetes élőhelyre, melybe az ott előforduló állatokból telepítettek némileg dúsított mennyiségben, majd két hónapon át mintákat vettek, hogy a nitrogénfelvétel dinamikáját meghatározhassák. Mivel igen szép eredményeket kaptak, a Nature folyóirathoz nyújtották be kéziratukat. Nem fogadták el közlésre. Ennek a ballépésnek tanulsága az, hogy érdemes a tapasztalt professzorokra hallgatni. Elöadó VÁSÁRHELYI TAMÁSsal közösen részt vett a Balaton-kutatásban. A tó medencéi különböztek egymástól a trofitás szempontjából. Tőlük független kortárs adatok, továbbá régi gyüjtések adatai is rendelkezésre álltak. A vízipoloska-együttesek eltértek az egyes medencékben, és a történeti adatoktól is különböztek. Egy elismert folyóiratban közölték eredményeiket, ám a befektetett munka mennyiségéhez képest eddig igen kevesen idézték. Viszont a korábbi eseményekből kiindulva már csak néhány évtizedet kell várniuk, hogy az idézettség növekedjen.

\section{VÁSÁRHELYI TAMÁS: A beporzók napja}

A beporzók egyedszáma vészesen csökken, ami a rovarvilág pusztulásának tünete. Németországban egy vizsgálatban 27 év alatt negyedére csökkent az azonos helyen megfogott repülö rovarok tömege. A repceföldek 2 héten át nyújtanak táplálékforrást, ezen kívül semmilyen élőhelyet, búvóhelyet nem adnak. A pusztulás fó oka az élöhelyek leromlása, a környezetszennyezés és a klímaváltozás. Az Európai Unióban tavaly betiltották háromféle neonikotinoid rovarirtószer használatát. A beporzók napjának bevezetését egy hallgatójával együtt kezdeményezték 2018-ban. Az első évben 20-nál is több helyszínen tartottak rendezvényt, határainkon innen és túl. A beporzók napja egyik célja a beporzók pozitív oldalá- 
nak hangsúlyozása, szemléletformálás. A kezdeményezés mellé állt több civil szervezet, sőt a biológus szakma számos jelentős szervezete is. A szemléletformálásnak része volt pl. rovarbarát kertmüvelési tanácsok nyújtása, rovarbölcsők készítése. Kérdés, van-e értelme egy, nagyüzemi mezőgazdaság által keltett problémára lakossági választ várni. Úgy tünik, van: a városokban a kertek a legfajgazdagabbak, itt segíteni tudnak.

\section{Kondorosy ElÖD: Poloskák a Kárpát-medencében.}

HORVÁTH GÉZA volt az első kiemelkedő, szipókás rovarokkal foglalkozó kutató hazánkban. Fajleírásai közül kb. 800 még ma is érvényes. Hazánk mai területéröl 600 poloskafajt mutatott ki. Halála után e rovarcsoport kutatását sokáig mellőzték, majd csak a II. világháborút követő évektől lendült fel újra, föleg a Fauna Hungariae sorozat poloskás köteteinek megjelenései idején. A fajok harmadát kitevő mezeipoloskák egyik kötetben sem szerepelnek. A kutatások később, a nemzeti parkok és egyes természetvédelmi területek faunájának feltárása idején ismét megélénkültek. Az utóbbi időben viszonylag kevés, hazai faunára új faj került elő. Ilyenek felbukkanása visszavezethető rendszertani okokra (fajok szétválasztása), alacsony denzitásra (specialisták, elterjedési területük peremén élő fajok) vagy új betelepülésre. Több csoport fajait csak ivarszervi vizsgálattal lehet elkülöníteni. Specialista fajokat találtak korábban alig kutatott élőhelyeken, pl. lápokban. Hegyvidéki fajok is kerültek elö. Néha nehéz eldönteni, hogy egy-egy faj őshonos-e vagy adventív. A poloskász-gyakorlatban általában száz év a határ, kivéve, ha ismert a behurcolás konkrét eseménye. Ezenkívül néhány kritérium segíthet eldönteni a kérdést, pl. ha tápnövénye nem őshonos, akkor a poloskafaj sem; ha városban találták, akkor valószínüleg szintén idegen; viszont ha hegyvidéki, akkor kevésbé terjedhetett az elmúlt időben, így valószínủleg őshonos. Az utóbbi évtizedben érkezett a legtöbb Európán kívüli faj. A hársbodobács is jövevény. Hazánkból jelenleg több, mint 800 poloskafaj ismert. MERKL OTTÓ felidézte, hogy Előadó szerint a hazánkból legalább 40 éve ismert fajok valószínüleg őshonosak. KONDOROSY ELŐD ezt a határvonalat a klímaváltozás hatásainak érzékelésével indokolta, hozzátéve, hogy igen spekulatív dologról van szó. MERKL OTTÓ: Léteznek ugyanakkor már 1920 óta velünk élő, nem őshonos fajok is. KONDOROSY ELŐD: Így van, viszont ezekben az esetekben ismert a behurcolás ténye, időpontja.

NAGY PÉTER elnök úr lezárta az előadóülést, és eredményes nyarat, jó pihenést kívánt.

\section{2., ünnepi előadóülés, 2019. szeptember 20-án}

A Magyar Rovartani Társaság és a Szakosztály közösen tartotta ezt az elöadóülést, a Magyar Természettudományi Múzeum Ludovika téri kiállítási épületében. A levezető elnök ezúttal VIG KÁROLY, a Magyar Rovartani Társaság elnöke volt.

1. VIG KÁROLY: A Magyar Rovartani Társaság köszönti VARGA ZOLTÁNT.

Előadó VARGA ZOLTÁNnal 1981-ben találkozott először. Ekkor még irigykedve tekintett azokra a hallgatókra, akik töle tanulhattak, hiszen nagyon kevés, hozzá mérhető kvalitású szakembert ismer. Köszöntését oklevél átnyújtásával zárta. 
2. NAGY PÉTER: A 80 éves VARGA ZOLTÁN professzor úr köszöntése a Magyar Biológiai Társaság Állattani Szakosztálya részéröl.

VARGA ZOLTÁN a Szakosztályban eddig 14 előadást tartott, igen változatos témákban, ami mintegy 40 évi időszakot ível át. Előadásainak zömét már befutott, elismert kutatóként tartotta, amivel példát mutat a többi biológus kutatónak. Megkapta a Táraság HERMAN OTTÓ-díját. A Magyar Madártani és Természetvédelmi Egyesület örökös tagja. „Állatismeret” címü munkájával több nemzedék ismeretterjesztésében vállalt szerepet; a könyvnek nemcsak szövegét írta, hanem színes tábláit is ő rajzolta.

3. GyULAI PÉTER: Sok éves közös munka VARGA ZOLTÁNnal: új Noctuidae fajok és élöhelyeik Ázsiában.

$\mathrm{Az}$ előadásba olyan lepkefajok és élőhelyeik fényképei kerültek, amelyeket Szerző VARGA ZOLTÁNnal (és esetenként másokkal) közösen írt le, együtt gyüjtöttek, vagy másképpen kötődik Ünnepelthez. Az ő nevét viseli a Dichagyris vargazoli nevü lepke, mely a Tibeti-plató keleti részén él. A Tibeti-fennsíkról több bagolylepke-fajt is leírtak. Mongóliából is sok tudományra új faj került elő, itt 2000 m magasságban szikes puszta és félsivatag határán is gyüjtöttek. Északkelet-Iránban, a Kopet-Dag hegységben is gyüjtöttek, az ország legmagasabb hegyén, a Demavenden szintén jártak. Ám nemcsak hegyvidéket, hanem sivatagot is felkerestek. A Zagrosz-hegységben legeltetéstől mentesült területeket találtak, ami Iránban ritkaság. Több lelőhelyet éveken át kutattak, mindig más-más aszpektusban. KeletTörökországban szintén megfordultak. Összesen 20 bagolylepkefajt vagy -alfajt mutatott be Előadó. VARGA ZOLTÁNnak köszönheti, hogy lepkészete tudományos irányultságot vett.

4. NAgY Antal, RÁCZ István AndRÁs és SZANYI SZABOlCS: A Beregi-sík egyenesszárnyú faunájának kutatása.

A Beregi-sík a Pannon biogeográfiai régióban számos hatást kap: a kárpáti és a déli faunakör tagjai egyaránt jelen vannak. Jelenleg országhatár szeli ketté. Eredetileg erősen vízjárta terület volt. Újabban a müvelt területeket részben felhagyták. A területen kevés kutatás zajlott. Szerzők célja elterjedési adatok gyüjtése különös tekintettel a védett fajokra, fajegyüttesek jellemzése, a terület jövőbeni védelme érdekében. Összesen 48 fajt találtak meg a magyarországi oldalon, míg az ukrajnai területen 52 faj került elö; a két terület fajösszetétele nagyrészt átfed, az összesített fajszám magasnak mondható. Az Isophya stysi Natura 2000 tarszának sok új lelőhelyét találták, az Odontopodisma rubripes sáska pedig szerte a területen előfordul, sokféle élöhelyen. A fajegyüttesek tekintetében három csoportot tudtak elkülöníteni: a nedves gyepek, a száraz gyepek együtteseit, valamint egy átmeneti csoportot; ezek főleg az életformatípusok eloszlásában különböznek. Leginkább az élőhely szerkezete befolyásolja az együttes összetételét. A nedves gyepekben fordult elő a legtöbb karakterfaj. A vizsgálat fő tanulsága, hogy még az ismertnek tartott fajokról is kiderülhetnek új információk, akár a benépesített élőhelyek fajtájában is. Szerző mindenkit buzdít faunisztikai adatainak közzétételére.

\section{RÁCZ ISTVÁN ANDRÁs: Tücsökmese másképp...}

A tücskök és a többi egyenesszárnyú valóban léha zenészek lennének? Nem: nekik is megvan a helyük az életközösségekben. Söt, igen érdekes viselkedést is mutathatnak. 2010ben fedezték fel, hogy az egyik, Réunion szigetén honos orchideafajt egy endemikus szöcske porozza be. Az orchidea közelrokon fajait madarak porozzák be, más fajtestvéreit rovarok. A szöcske rágói eltompultak, ám képessé vált a nektár elfogyasztására. Később más 
pollinátor szöcskefajt is találtak, amely viszont több növényfaj virágait is beporozhatja. Egy újabb vizsgálatban már 40 egyenesszárnyú-fajról bizonyosodott be, hogy pollinátor feladatokat is ellátnak, ezek leginkább fészkeseket látogatnak. Az egyik szöcskefaj pollennel táplálkozik, tapogatóival söpri szájnyílásába. Közben testére is tapad virágpor, melyet így virágról-virágra hurcol. Tehát a mese vége: mindenki teszi a dolgát, ha hagyjuk, valamint olyan csoportok végezhetnek beporzást, melyekröl nem gondoltuk volna.

6. TARTALLY ANDRÁS: A hangyaboglárka lepkék hangyagazda használatának alakulása térben és időben.

A Magyar Rovartani Társaság tagjai előtt először tart előadást. Gyerekkorában sokat forgatta az Állatismeretet. Hazánkban négy hangyaboglárka faj (Maculinea spp.) honos, melyek hernyói életük nagy részét hangyabolyban töltik, föleg kétbütykös hangyák (Myrmica spp.) bolyaiban. A lepkék tápnövény-tövei körül $2 \mathrm{~m}$ sugarú körben vizsgálta a hangyabolyokat. A M. scabrinodis volt a leggyakoribb hangyagazda nálunk (újabban egyesek több fajra bontják). A szürkés hangyaboglárka (M. alcon) nedvesréti alakja e hangyafajt használja inkább, viszont a szárazréti ökotípus más hangyákat választ. A nagypettyes hangyaboglárkáról (M. arion) összesen két adatot sikerült szerezniük: legalább két hangyafaj a gazdája. A kispettyes hangyaboglárka ( $M$. teleius) alkalmazkodik: azt a hangyafajt használja, amely éppen rendelkezésre áll. A sötétaljú hangyaboglárka (M. nausithous) viszont csak a $M$. rubra fajjal él együtt. A szárazréti szürkés hangyaboglárkánál azt is vizsgálták, hogy mennyire képesek követni a kaszálórétek felhagyása miatt megváltozó hangyaközösségeket. Eredményeik szerint a kezelt réteken megvan a lepke, míg a felhagyott rétekről eltünik. A lepkebábok néha fürkészdarázzsal voltak fertözöttek: olyan allomont bocsát ki, amelynek hatására a hangyák összeverekednek egymással; a darázs ezt kihasználva hatol a bolyba és tojja petéjét a boglárka hernyójába.

\section{RONKAY LÁSZLÓ: Kalandozás lepkeszárnyon Eurázsiában.}

VARGA ZOLTÁN hatalmas területet járt be bagolylepkéket kutatva, az előadás néhány fontosabb gyüjtőhelyet és onnan leírt lepkét mutatott be. Előadó még gyermekkorában megdöbbent azon, hogy hazánkban is lehet új bagolylepke fajt felfedezni (KovÁCS LAJOS és VARGA ZOLTÁN írta le a Tallós-dudvabaglyot). Előadó és VARGA ZOLTÁN elsőként Bulgáriából írtak le közösen egy fajt. Az Olimposzon új bagolylepke-alfajt fedeztek fel. Következő állomásunk Kappadókia (Törökország) nagyon változatos felszínủ világa. Északkelet-Törökországban sok faj bizonyult tudományra újnak, főleg a késő őszi faunából. Örményországban is jártak, többek között a Kaukázusban. Iránból a Demavend ebben az előadásban is előkerült. Türkmenisztán volt az egyetlen hely, ahol Előadó és VARGA ZOLTÁN hosszabb közös gyüjtőúton vett részt, itt az egyik gyüjtőhelyen egy genuszból három leíratlan fajt is találtak. A Központi-Hindukus vidékén, majd a Keleti-Hindukusban, Afganisztánban is megfordult VARGA ZOLTÁN. Pakisztánban a Sandur-hágó igen érdekes helyszín. A Deosai-fennsík 4000 m feletti magasságban helyezkedik el, három nagy hegységrendszer (Karakoram, Hindukus, Himalája) találkozásánál. Mongóliában is többfelé gyüjtött, és az Altai-, valamint a Tien-san hegységekben is igen sok leíratlan fajt fedezett fel. Az előadásban 50 bagolylepke-taxonról és számos szép helyszínről láthattunk fényképet.

Az előadóülés végén VARGA ZOLTÁN köszönetképpen pályájának elindulását mutatta be, majd gyüjtőtársairól emlékezett meg egy rövid elöadásban. KovÁCs LAJOShoz kezdett 
középiskolás korában bejárni az Állattárba. Közös munkájuk lett KASZAB ZOLTÁN mongóliai anyagának feldolgozása. Ez az anyag páratlan mennyiségü, minőségü és sokféleségü. Münchenbe kijuthatott még ebben az időben, ahol GUSTAV DE LATTINnal, a biogeográfia nagy hatású müvelőjével ismerkedett meg. A sok expedíción számos gyüjtőtárssal közösen vettek részt, és nem kevés helybéli segítővel, baráttal ismerkedtek meg. 